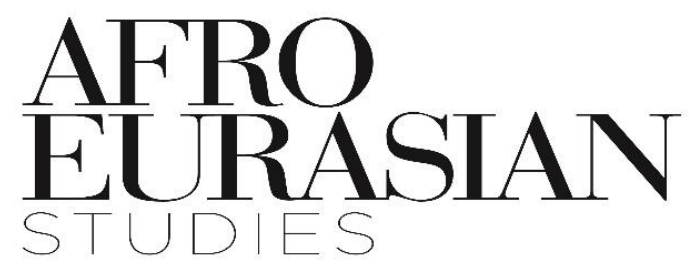

[AFES], 2019, 8 (1): 8-38

Is The Dutch Disease Valid for Turkey in terms of the Effects of Portfolio Investments and Export Revenues on the Manufacturing Industry?

Ali KONAK

Asst. Prof., Lecturer, Karabuk University Department of Economics, Faculty of Economics and Administrative Sciences,

alikonak@karabuk.edu.tr,

Orcid Id: 0000-0003-1804-8339

Article Information

Article Types : Research Article

Received : 23.02 .2019

Accepted : 28.03.2019

Published : 28.03.2019

Pub Date Season: March 2019

Cite as: KONAK, A. (2019). Reviewed Is The Dutch Disease Valid For Turkey in terms of the Effects of Portfolio Investments and Export Revenues on the Manufacturing Industry? . Afro Eurasian Studies, 8 (1), 8-38. Retrieved from http://dergipark.gov.tr/afes/issue/44214/531548 reviewed

Plagiarism: This article has been reviewed by at least two referees and scanned via a plagiarism software.

Copyright () Published by MUSIAD- Ataköy 7-8-9-10 Mah. Cobancesme E5 Yanyol Cad. No:4 Bakirkoy, 34158 Istanbul / Turkey Tel +90 (212) 3953302 Fax +90 (212) 3950001 aestudies@musiad.org.tr 


\title{
Is The Dutch Disease Valid for Turkey in terms of the Effects of Portfolio Investments and Export Revenues on the Manufacturing Industry?
}

\begin{abstract}
The Dutch disease which emerges as a result of suddenly finding a large amount of commercially valuable mines, is an economical issue which has an effect on various macroeconomic variables, notably on foreign exchange rate. Although in theory, the Dutch disease is defined as a problem caused by foreign currency which is acquired by the detection and exportation of valuable mines in the long term, it is possible for other economic developments which provide inflow of foreign currency to the country to have economical effects on the national economy that are similar to the effects of the Dutch disease. In our study in which we question the existence of the Dutch disease due to the inflow of foreign currency through various channels, the effects of portfolio investments and export revenues on manufacturing industry sector were analyzed in terms of the hypothesis of the Dutch disease by using the quarterly data of 2005:Q12018:Q4, obtained from the Electronic Data Delivery System (EDDS) of The Central Bank of the Republic of Turkey (CBRT) and by using Toda-Yamamoto causality test. As a result of the analysis, there wasn't a causal relationship between manufacturing industry and portfolio investments and exports. For this reason, it was concluded that the Dutch disease is out of the question for Turkey's economy.
\end{abstract}

Keywords: The Dutch Disease, Industrial Production Index, Portfolio Investments, Export, Toda-Yamamoto Causality Test. 


\section{Introduction}

Economic growth and development constitute one of the and maybe the most important primary objective of all the countries of which they want to achieve economically. In order for economic growth to take place, investments should be encouraged towards many sectors and especially manufacturing industry sector. In the procurement of resources that would lead to investments, many resources can be utilized. One of these resources is the revenue that is obtained from the exportation of precious metals and natural resources that are possessed by the country and has commercial value. However, at this point countries should be careful and take required precautions against the Dutch disease which can be caused by foreign currency earnings that would be obtained from the exportation of valuable natural resources they possess. In the case of the Dutch disease which emerges as a result of natural resources wealth, the increasing amount of foreign currency in the country after the export of the natural resources such as natural gas and petroleum causes the appraisal of national currency and this situation affects many macroeconomic variables such as production volume, unemployment, foreign exchange rate and foreign trade deficit and especially economic growth. Due to the natural resource exportation that has commercial value of a country, inflow of foreign currency to that country will take place.

Natural resource exportation does not have to increase in order for Dutch disease to emerge. Various economic developments that would provide the inflow of foreign currency may cause the Dutch disease as well. Especially transferring the savings of workers who work in abroad, increases that occur in the tourism revenues as a result of getting into debt from international market and portfolio investments may cause the emergence of the Dutch disease. Turkey is not a country which has natural resource wealth. However, substantial amount of inflow of foreign currency take place in Turkey through the channels that were mentioned above. The determination of whether or not the foreign currencies that enter to Turkey by various ways has an effect on macroeconomic variables with the aforementioned mechanisms, in other words, whether or not this situation causes the Dutch disease in Turkey is an important subject that should be examined. In this study which was conducted in order to clarify this 
subject, first the Dutch disease was explained theoretically, then the effects of the Dutch disease on macroeconomic variables were generally discussed and the Dutch disease was examined in the context of Turkey. Lastly, econometric analysis was conducted in order to determine whether or not there is Dutch disease in Turkey

\section{The Dutch Disease}

Developments that seem positive in terms of economics may not always give positive results. One of the clearest examples of these is an economical problem called as the Dutch disease. The existence of petroleum and natural gas in certain countries and the exportation of these commercially valuable mines cause an increase in the inflow of foreign currency to the country and the increase in the amount of foreign currency makes the national currency more valuable. The appraisal of natural currency causes an increase in import and correspondingly, causes decrease in the output of manufacturing industry sectors and level of employment (deindustrialization). This negative condition is defined as the Dutch disease (Akça and Bal, 2017: 52). In their study, Corden and Neary (1982:841) who laid the theoretical foundations of the Dutch disease, defined the results of this disease as "deindustrialization", that is, the deindustrialization of a country. Although the Dutch disease dates back a long time, it is essentially an economical phenomenon that emerged in 1970's. The economical phenomenon defined as the Dutch disease was first observed in The North Sea near Holland in 1960's as a result of finding natural gas and this phenomenon was named as "The Dutch Disease" in the late 1970's by the journal The Economist. Natural gas reserves that were found in 1960's caused Holland to become a significant energy exporter in the late 1970's. This positive development which made the country wealthy in terms of foreign currency, caused certain economic problems to arise after some time (Suleymanov and Hasanov, 2013:89). The leading problem among these problems is the slowdown of production activities and economic growth. In the process of the emergence of the Dutch disease, first the national currency increases in value excessively due to the increase of income that is obtained from the exportation of natural resources and then since the national currency is valuable, the required goods and services of the consumers are obtained by importing them 
and for this reason production activities and economic growth in the domestic market slows down (Gylfason, 2001: 848-850). Furthermore, since it is possible to obtain goods and services that are required in a country cheap through importation due to the appraisal of national currency, the consumption of imported goods increases and thus increases occur in the current account deficit. Along with this, in parallel to the increase in the consumption of imported goods, constrictions in the domestic production volume and increases in the employment occur. Especially, the declines in the production volume of manufacturing industry and the level of employment are regarded as signs of the initiation of deindustrialization process (Peck, 2005:135). Furthermore, due to the decline in the sectors apart from natural resources sector and the profitability decrease in these sectors, may cause decreases in foreign direct investments (capital export) that come to the country. In addition to these negativities, the decline process of the industry caused by the Dutch disease can affect other sectors in the country either directly or indirectly.

Turkey does not possess rich natural resource reserves, strong industry or a consistent export potential like Holland or other countries that are wealthy due to natural resources. However, it is not necessary to possess natural resources in order to experience the Dutch disease. Hot money flow due to the increases in interest rates, increases in workers' remittances, increases in tourism incomes and large amounts of foreign currencies that come to the country due to the large-scale investments because of the strategic location of the country may cause same effects and results on the national economy. At this point, it is possible to state that the Dutch disease does not solely emerge due to the incomes that are obtained through natural resources, but foreign currency inflows that take place in various ways may also cause the Dutch disease.

\section{The Effect of the Dutch Disease on Various Macroeconomic Variables}

The Dutch disease emerges as an economical problem that originates from the abundance of natural resource and defines the deindustrialization process. For this economical problem of which derives from the deindustrialization, it is possible to state that it has significant effects on many macroeconomic variables, notably as, per capita income, economic growth, foreign trade deficit, 
current account deficit and unemployment. At this point, it is beneficial to emphasize these concepts.

\section{The Effects of the Dutch Disease on GNP and Per Capita Income}

Eğilmez (2013) defines the per capita income as an average value that is obtained through dividing the Gross National Product to the population of the country. The annual income of the people in the country may be far below or above the average income that is obtained through dividing the total Gross National Product to the population of the country. For this reason, per capita income is just an average value. In addition to this, Gross Domestic Product (GDP) is regarded as one of the indicators of welfare and life standard in a country (Aliev, 2013:136). In other words, the increases in per capita income mean improvements in the life standard of the individuals. The increase in the per capita income is closely related to the increase in the amount of capital that would flow the country in various ways. At this point, the Dutch disease appears as an economical problem that directly affects per capita income. At the beginning of the Dutch disease, the inflow of substantial amounts of foreign currency due to the exportation causes a significant increase in the Gross National Product and thus, an increase in the amount of per capita income and this causes an artificial and temporary increase in the life standards of the individuals.

\section{The Effects of the Dutch Disease on Manufacturing Industry and Economic Growth}

The economical process defined as the Dutch disease has significant effects on the Gross National Product and economic growth. The economic growth which is one of the most important indicators of a developed country, is affected by economic process called as the Dutch disease through various channels and in considerable amounts. In other words, finding a natural resource suddenly and with a considerable amount of reserve in any country has several significant effects on economic growth. Finding a natural resource suddenly and with a considerable amount of reserve after the search operations and revisions, causes a country to be wealthy in terms of natural resources. Furthermore, since in this process the natural resources sector of a country will be more important 
compared to the previous periods, the employees and employers working in this sector start to earn higher incomes than the employees working in other sectors. For this reason, a considerable part of production factors, notably as labor factor, face towards this sector in which high financial gains can be acquired. Furthermore, in this process, increases take place in the investments of the sectors that are active in the production of natural resources, thus, the demand for labor in natural resources sector increases as well (Akça and Bal, 2017: 53). In contrast with this, apart from the sectors that are operating in the production of natural resources, the process of downsizing takes place as a natural reflection of this process and this downsizing process causes a decrease in the amount of production for these sectors. In other words, this process causes the sectors that are operating apart from the production of natural resources to fall behind and the emergence of deindustrialization problem for these sectors. Furthermore, this situation causes an increase in the price of goods and services that are produced in these sectors. The increases in the prices of goods and services of these sectors of which majority of them are in industry sector, cause a decrease in the competitive power of these sectors and thus, the process of deindustrialization (Gurbanov, 2012: 2). Furthermore, manufacturing industry is also affected negatively from this process. This situation causes economic growth to be affected negatively. Moreover, planning the development of the country based on the wealth of natural resources and the exportation of these resources by the politicians causes a decrease in the interest to the other sectors in the country and thus, affects the technological development process and economic progress in these sectors negatively. In addition to this, the decrease in the interest to these sectors, decreases the interest to the training that is required in the process of production and the lack of trained labor that is required for the quality production to be produced, causes economic growth to be affected negatively (Gylfason, 20013: 854). More clearly, this deindustrialization process that emerges as a result of the Dutch disease and the lack or absence of trained labor operating in the sectors apart from the sectors that are operating in the production of natural resources, would naturally cause a reduction in the production volume of a country, reduction in the export revenues that are acquired through the sectors apart from the natural resources sector and cause economic growth to be affected negatively. In addition to this, 
the changes in the foreign exchange rates and the appraisal of national currency due to the Dutch disease have important effects on the manufacturing industry of a country. Appraising of natural currency by the foreign currencies that were acquired through the exportation of natural resources, cause goods and services which were requested either as intermediate requests that would be used in the process of production or the final goods and services that were requested to be consumed directly to be compensated through importation. Furthermore, the increases in the level of income of labors that are working in the sector of natural resources production are effective in the increase of demand for imported goods and service. Therefore, both the procurement of cheaper goods and services due to the appraisal of national currency and the increases in the level of income of labors working in the natural resources sector, directed the consumers to demand imported goods. This situation at the same time means the decrease in the demand for goods and services that are produced in the domestic market. This process prevents domestic industries to develop, to fall behind and causes national companies to downsize in terms of production activities. Downsizing by the domestic industry causes a decrease in the production volume on a national basis, a decrease in the exportation of the products in this sector and a slowdown of the economic growth due to the decrease in the export revenue.

\section{The Effects of the Dutch Disease on the Foreign Trade}

Another negative effect of the Dutch disease which has significant economic effects on the macroeconomic variables, is observed in foreign trade. Foreign trade is a concept that was emerged as an extension of the reality that no country can possess all of the production factors. The unbalanced distribution of production factors and natural resources, the technological and economic development differences among the countries and not producing or insufficiently producing the required goods in the country due to the differences of possessing skilled labor, made foreign trade to be inevitable. In this context, it is possible to define the foreign trade as replacing the goods and capital into and out of the national borders as exporting and importing, and especially exportation has an important place in the development of a country. In his study, Taylor (2002: 29), states that foreign trade provides the opportunity to find the best product in global markets and to make the best deal for the consumers and 
for the trading companies. In addition to this, it was stated that getting into competition by national companies which operate in foreign trade, with international companies would have positive effects on the efficiency and profitability (Demir et al. 2005: 181). Grossman and Helpman (1990: 11) state that benefits that would be acquired through the contracts that are made with foreign businesspeople due to foreign trade and supporting the R\&D activities would affect national economy positively. In addition to all of these elements, foreign trade gives the opportunity to benefit from all of these advantages that are provided by the scale economies by enabling a production opportunity to the local producers for a larger market. In this process, technological development that is provided through foreign trade and the fierce competition environment, make a great contribution to the economic growth. Foreign trade which has significant effects on the development of the country and seen as one of the basic factors of economic growth, is affected negatively in the process of the Dutch disease due to the ineffective distribution of production factors and natural resources.

Apart from this, especially the increase in the amount of natural resource's supply that earns foreign currency causes a significant amount of foreign currency inflow and appraises national currency. Overvaluation of national currency causes an increase in current account deficit (Karacan, 2010: 76). Furthermore, the increases in the incomes of labors operating in the sectors based on the supply of natural resource, naturally cause an increase in the demand of imported goods and services. In this process, labor and financial resource transfer from other sectors to the sectors, energy sector in particular, that are operating in the production of natural resources cause significant decreases in the amount of production in other sectors and thus, significant increases in the product prices (Akça and Bal, 2017: 53). These two effects, that is, the appraisal of national currency due to the inflow of foreign currency and the increases in the incomes of labors that are working in the fields related to the production of natural resources, cause an increase in the importation and the emergence of foreign trade deficits. Especially, using the incomes that are obtained through natural resources (petroleum) for the importation of consumption goods instead of investment goods plays an important role in the foreign trade deficit (Bulut and Suleymanov, 2012: 108). In order to narrow the 
foreign trade deficit that emerges as a result of this process, the revenues that are obtained through the exportation of natural resource are used and the positive effects of the revenues that are obtained after the exportation remain limited.

\section{The Effects of the Dutch Disease on current account deficit}

One of the important macroeconomic indicators that should be considered is the current account deficit. Current account deficit is defined as having more foreign aid, workers' remittances and export proceeds than the country's interest expenses, profit transfers and the payments it make for the import as a result of economical and commercial activities that is conducted with the rest of the world. In order to determine the current account deficit, it is extremely important to monitor the balance of current account. In the balance of current account, mainly the differences between the importation and exportation of commercial goods and services, investments, incomes and transfers are included. A large part of this difference derives from foreign trade. Therefore, the existence of current account deficit in a country means that the importation occurs more than the exportation since the needs are compensated through import due to the lack of sufficient production in that country. More clearly, current account deficit emerges when the amount of consumption is more than the domestic production (Seyidoğlu, 2009, p.404). Cannot compensating the required goods and services with the domestic production, necessitates importation and this situation causes current account deficit to enhance. Therefore, this process causes the foreign trade deficit and subsequently current account deficit to increase. For this reason, closely following the changes that take place in the level of current account deficit and determining the reasons that cause current account deficit correctly, are extremely important in terms of preventing the problems on time that may be encountered (Erdogan and Bozkurt, 2009: 137). In addition to this, if there is a problem of current account deficit and if several solutions are not produced for this problem in a short time, the provision of resources that are required for the solution of current account deficit in upcoming periods causes the country's external debt burden to increase and in the long-term, the solution of current account deficit becomes far more difficult. Furthermore, in this process, if the resources that are obtained 
through external indebtedness will not be used in a way which would generate income, several problems may be encountered in the payment of external debts and fluctuations may occur on financial markets. In this context, current account deficit is one of the most important economic problems that countries should struggle. For this reason, countries should be extremely careful both in the resource selection that would be provided in order to meet the current account deficit and the usage of the provided resources.

\section{The Effects of the Dutch Disease on the Employment.}

Another important economical problem that is caused by the Dutch disease is unemployment. With the unemployment concept, a situation of not finding a job although people want to work in valid conditions in the market is defined. Today, significant increases are observed in the population of workable age group (age of 15-64) especially in developing countries. In contrast with this, the increase in the employment capacity of a country does not take place at the same ratio with the increase in the population (Aksu, 2017: 41). This situation causes the emergence on unemployment problem. The unemployment problem is directly associated with the amount of production of a country. In economic recession periods, there are decreases in the demand of goods and services and these decreases require a decrease in the amount of production. In these periods when an economically recession and narrowing take place, companies either decrease the working hours or the wages of employees before relieving them of their duty. However, the prolongation of economic recession forces companies to lay off their employees and therefore, unemployment increases (Akay et al. 2016: 210). The increase of import that emerges due to the appraisal of national currency in the process of the Dutch disease caused real investments to regress and unemployment to increase in many national sectors. The sudden and fast increase of the production of valuable mines in a country such as petroleum and natural gas and the increases in the exportation correspondingly, cause the welfare of consumers to increase. In addition to the increase in the consumer welfare, the appraisal of national currency cause the increase in the demand of goods and services to be towards imported goods. As the inflow of foreign currency due to the sale of valuable mine and the welfare of the consumer continue, the consumption of the imported goods also continues to increase 
(Boyraz, 2014). In this process, the increase in the majority of the consumption towards the imported products means a decrease in the consumption of the goods and services that are produced in the country and thus, the production of these goods and services and this situation causes increases in the unemployment. In other words, the deindustrialization process caused by the Dutch disease constitute another important reason for the decrease in the employment.

\section{The Dutch Disease and Turkey}

When the Dutch disease is evaluated within the context of Turkey, different source but same results can be encountered. As far as we know, the Dutch disease is the negative economic developments that are caused by the increases in the foreign exchange earnings due to the increase in the amount of natural resources and the appraisal of national currency. Since the inflow of foreign currency in high numbers is not only related to the possession of natural resource, the Dutch disease is not an economical problem that should be struggled against only by countries that are wealthy in terms of natural resource. It is possible to encounter the Dutch disease in developing countries such as Turkey where capital flow takes place through various economic channels and economic reasons that are different from each other. A significant transfer of resource to Turkey, which started to provide young labor for European countries in 1970's, was performed by the Turkish workers who went abroad to work. Workers' remittance accounts by which the foreign currencies are transferred by the workers in abroad to Turkey, became considerable in size in the balance of the CBRT over time and had a significant share in the assets. In accordance with the studies it was concluded that workers' remittances caused the emergence of deindustrialization tendencies in the country due to certain structural changes. In addition to this, a rapid change took place in the consumption structure of a part of the country's population due to the increase in the workers' remittances (Gurbanov, 1999: 95-96:105). However, the Dutch disease may originate from other economic developments that provide the high amounts of inflow of foreign currency, besides the possession of natural resource. Therefore, the main and bigger problem is the inflow of hot money due to the political and economic problems in the country. At this point, foreign 
currency flows to the countries which are wealthy in terms of natural resource through the exportation of natural resource, and it flows to the developing countries like Turkey through political and economic problems.

The increase in the demand of imported goods with the mechanism of free market after the 1980's in Turkey caused an increase in the expenses at first and it became necessary to borrow from international markets through various ways due to the exceeding of these expenses from the revenues and these borrowings was able to happen due to high interest rates and therefore significant amounts of hot money inflow took place. Hot money inflows had various economic effects on Turkey's economy, similar to the economic effects of the discovery of a rich natural resource that emerges suddenly on the national economy. Although hot money inflow to Turkey seemed to give positive results in terms of the economy, this hot money could leave the country quickly in the case of negative economic and political developments and could have prevented the economic growth in long-term by causing serious problems first in the financial markets and then in the real markets (Aytekin, 2018: 206). In other words, the inflow of hot money took place due to high interest rates, national currency increased in value for a while and importation became relatively cheap. The appraisal of national currency also caused an increase in the demand for production (Eşiyok, 2012: 70-71). However, the increase in the demand for consumption in this process was mainly towards imported goods and for this reason it is possible to state that the national industry regressed and unemployment increased. In addition to this, since the privatization activities have been accelerated lately in Turkey and it became a secure country to invest due to the political stability, it caused an acceleration in the inflows of foreign currencies either as real investment or as hot money. However, the abundant amount of hot money that inflows to the country through aforementioned reasons, causes national currency to be extremely valuable and the demand and production of the exportable goods to decrease. The appraisal of national income causes imported goods to be cheaper for national currency and for this reason domestic demand change its direction from import substitutes to the imported goods (Humphrey 2004: 17). Furthermore, the appraisal of national income, negatively affects the industry of the country by causing an increase in the imported input usage in the production process. In the period after 1980, 
with the economic liberalization, a similar process took place in Turkey's economy as well. Foreign currency that flew to the country through various ways, negatively affected the national industry by causing the appraisal of national currency and the usage of imported input in the production process. The reasons of this process in Turkey is similar to the reasons of the Dutch disease with a different source and the induced negative results are also similar for any reason whatsoever.

\section{Literature}

Plenty of studies were conducted about the Dutch disease either local or foreign. It is possible to state these studies chronologically.

In their study, Kutan and Wyzan (2005) examined the Kazakhstan economy of which substantial amounts of export revenues are acquired through expanded natural resource reserves, for the period of 1996-2003 by using BalassaSamuelson model which was expanded in order to include the effects of petroleum prices, in terms of the Dutch disease. As a result of the examination, it was determined that since 1991 when the independence was gained, the exportation of Kazakhstan is conducted mainly through sectors related to the energy and the changes in the prices of petroleum has important effects on the real foreign exchange rates and due the appraisal of real foreign exchange rate, the effects of the Dutch disease are observed.

In their study of which they examined the Dutch disease by using growth models, Matsen and Torvik (2005) determined that the abundance of natural reserves in the country caused economic shrinkage by having certain negative effects on the economy and thus causing the Dutch disease.

In his study, Örnek (2006), analyzed the causality relationships between the foreign capital inflows and domestic savings by using the quarterly data of Turkey's 1996:4-2006:1 period. As a result of the econometric analysis, direct foreign capital investments positively affect domestic savings both in short-term and long-term, but it has been concluded that short-term capital movements negatively affects domestic savings both in short-term and in long-term. 
In their study which was conducted in Cape Verde to examine the effects of immigrants' foreign currencies on real foreign exchange rate, Bourdet and Falck (2006) determined that the money sent by the immigrants cause some sort of the Dutch disease and this situation negatively affects the competitive capacity of tradable sectors.

In their study, Nowak and Sahli (2007) examined the effects of positive developments that take place in the economies of island countries on the economic growth in terms of the Dutch disease and evaluated the net economic effects of these countries' tourism revenues. As a result of examinations and evaluations, it was concluded that the increase in the tourism revenues may cause decreases in welfare.

Acosto, Lartey and Mandelman (2009) developed the two-sectored dynamic stochastic general equilibrium model in order to analyze the effects of remitted money of immigrants to the country on the developing market economies and used it in order to make assumptions. As a result of the analysis, it was concluded that the increase in immigrants' remittance cause a decrease in labor supply and an increase in the consumption demands that are prejudicial against non-trade sectors.

In their study of which Rajan and Subramanian (2011) examined the effects of economic aids on the growth of manufacturing industry by using a model that fixes possible reverse causality relationship, they reached a result that these aids caused several negative systematic effects on the competitive capacity and competitiveness of the country as it can also be understood from the decrease in the growth rate of industries that can export.

In their study which was prepared in order to analyze the possible effects and the direction of these effects of workers' remittances on the economic growth for the period of 1996-2006 in 30 developing countries, Ar1 and Özcan (2011) used Generalized Method of Moments (GMM) - (System method). As a result of the analysis, a positive relationship was determined between the increases in workers' remittances and the economic growth in the examined countries.

In their study which was conducted in order to examine the effects of obtained credits from IMF for the period of 1980-2009 on Turkey's economy in terms of 
macroeconomics and to determine whether or not these credits cause the Dutch disease, Parlakyıldız and Uçan (2012) conducted an analysis with cointegration and Error Correction Model (ECM) by using the annual data obtained from the IMF. As a result of the examinations and analyses, it was determined that IMF credits positively affect Turkey's economy in short-term but negative effects emerged in the long-term. In other words, it was concluded that due to the credits that were taken from the IMF, the real foreign exchange rate increased in value in Turkey, the competitive capacity of the country decreased and due to these developments in economic structure, indications of the Dutch disease was found.

In his study which was prepared in order to determine whether or not the Dutch disease is valid for Azerbaijan's economy for the period of 2000-2007, Hasanov (2013) determined that the direct foreign investments on petroleum sector and petroleum exportation negatively affected the sectors apart from petroleum sector and this caused the country to be more dependent on the petroleum, therefore the Dutch disease was valid for Azerbaijan economy.

In their study which was conducted in order to reveal the long-term relationship between the petroleum prices and the level of economic growth in 10 OPEC countries for the period of 1970-2011 and to determine whether or not the Dutch disease is valid for these OPEC countries, Yardımcıŏglu and Gülmez (2013) conducted Pedroni, Kao and Johansen Fisher cointegration tests and Canning; Pedroni panel causality analysis. As a result of the study, there was a significant interaction between the petroleum prices and economic growth in the examined OPEC countries in long-term and it has been concluded that there was a possibility of the Dutch disease for the analyzed OPEC countries.

In his study which was conducted in order to examine the effects of both petroleum prices and the increase in the petroleum reserves on petroleum exportation and to reveal whether or not these effects cause the Dutch disease to emerge, Benkhodja (2014) used multi-sectored dynamic stochastic general equilibrium model. As a result of the analysis, while the foreign exchange rate was stationary, it has been concluded that the Dutch disease emerged only when flexible wages and sticky prices are present. 
In their study which was conducted in order to examine the effects of hot money movements on the manufacturing industry sector of Turkey and accordingly to determine whether or not the Dutch disease is valid for Turkey's economy, Akçacı and Karata (2014) used the monthly data for the period of 2006:12013:12 that was obtained from (CBRT). As a result of their analysis in which Toda-Yamamoto (1995) and Hacker-Hatemi-J (2006) methods were used, they determined that there wasn't any causality relationship between the portfolio investments, manufacturing industry production index and export, furthermore, portfolio investments didn't cause the Dutch disease in Turkey.

In their study which was prepared in order to determine the existence of the Dutch disease in Central Asian Turkish Republics by using the data of 19902011, Mercan and Göçer (2014) used panel data analysis method. As a result of the analysis, it has been concluded that the increase in oil prices in the Central Asian Turkish Republics negatively affected the real exchange rate and that the Dutch disease did not apply to these countries.

As a result of their study which was prepared in order to explain the relationship between the changes in the real foreign exchange rate of ruble for the period of 2002-2013 and the transformation of Russia's economic structure, due to the excessive increases in the production of petroleum in Russia in 2000's, Mironov and Petronevich (2015) encountered several findings related to the existence of the Dutch disease.

In their study which was conducted in order to determine whether or not workers' remittances caused the emergence of the Dutch disease in Bangladesh, India, Pakistan and Sri Lanka for the period of 2003-2012, Roy and Dixon used fixed effects model. As a result of the analysis that was conducted with fixed effects model, it has been reached the result that the workers' remittances that were transferred to these countries had a statistically significant effect on the real currency.

In their study which was conducted in order to determine whether or not workers' remittances that have effects on important macroeconomic variables such as production, investment and employment, cause a real appraisal for the foreign exchange rate in the country and therefore whether or not this can cause 
the emergence of the Dutch disease, Akça and Bal (2017) used the data of 9 countries that acquires the most workers' remittances for the period of 19902014. As a result of the analysis which was conducted by using two-way random effects estimator, workers' remittances caused a real appraisal in the foreign exchange rates in the 9 examined countries, the existence of the Dutch disease was determined.

Destek et al. (2017), analyzed the relationship between petroleum income and agricultural added value in Azerbaijan, Kazakhstan, Kyrgyzstan and Uzbekistan for the period of 1991-2013 and the existence of the Dutch disease for these countries by using the ARDL border test. As a result of the analysis, there was a long-term relationship between the petroleum income and agricultural added value in Azerbaijan, Kazakhstan, Kyrgyzstan and Uzbekistan, however they concluded that the Dutch disease was only valid for Azerbaijan.

\section{Data Set, Econometric Model and the Interpretation of the Findings}

\subsection{Data Set and Econometric Model}

In this study, the effects of portfolio investments and export on the industrial production index in Turkey were examined. In this study of which the quarterly data for the period of 2005-2018 were used, 56 observations were performed. When the approximate variable (proxy) for the growth data included higher numbers of observation in the analysis, the industrial production index was created as "IPI", portfolio investments as "PI" and the export data as "EXP". The data that were used in the study were obtained from the Electronic Data Distribution System (EDDS) which is the database of CBRT.

The estimated model in the study was presented in the equation (1).

$\mathrm{IPI}_{\mathrm{t}}=\alpha_{0}+\beta_{1} \mathrm{PI}_{\mathrm{t}}+\beta_{2} \mathrm{EXP}_{\mathrm{t}}+\varepsilon_{\mathrm{t}}$

While the independent variables in the study are portfolio investments and export, the dependent variable is industrial production index. 


\subsection{Unit Root Test}

The series should be stationary in the studies in which time series was used. When studied with nonstationary series, the problem of spurious regression emerges in the regression analyses (Granger and Newbold, 1974: 111). For this reason, since the nonstationary series include unit root, the series are made stationary by differencing them. In order to test whether or not there is unit root in the series, two different tests are used.

\subsubsection{ADF Unit Root Test}

"The Augmented Dickey Fuller-ADF" unit root test which was developed by Dickey and Fuller (1981) is one of the most widely used method that is used in order to make the series stationary in time series. The basic ADF test equation is shown in the equation (2).

$$
\Delta Y_{t}=\beta_{1}+\beta_{2} t+\delta Y_{t-1}+\sum_{i=1}^{m} \alpha_{i} \Delta Y_{t-i}+\varepsilon_{t}
$$

In equation (2), $\Delta \mathrm{Y}$ shows the first difference of the variable, $\Delta \mathrm{Y}_{\mathrm{t}-1}$ shows the lagged value of the first difference. In order for ADF test to give consistent results, there shouldn't be sequential dependency problem in the discussed model (Gül and Ekinci, 2006: 95). While applying the ADF test, there shouldn't be correlation between the error terms and should possess constant variance (Petek and Çelik, 2017: 72).

ADF unit root test was applied to the variables in the study and the results of the study were given in Table 1. 


\section{Table 1: Results of ADF Unit Root Test}

\begin{tabular}{|l|l|ll|l|}
\hline Variables & $\begin{array}{l}\text { ADF } \\
\text { statistics }\end{array}$ & test & $\begin{array}{l}\text { Critical Values } \\
(\mathbf{\% 1 )} \\
(\mathbf{\% 5 )}\end{array}$ & Prob. \\
\hline IPI & -0.760343 & -3.565430 & - & 0.821 \\
& & 2.919952 & 6 \\
\hline PI & -4.040383 & -3.555023 & - & 0.002 \\
& & 2.915522 & 5 \\
\hline EXP & -1.398779 & -3.562669 & - & 0.575 \\
& & 2.918778 & 9 \\
\hline$\Delta$ IPI & -5.938132 & -3.560019 & - & 0.000 \\
& & 2.917650 & 0 \\
\hline$\Delta$ EXP & -5.123691 & -3.562669 & -0.000 \\
& & 2.918778 & 1 \\
\hline
\end{tabular}

According to Table 1, while the portfolio investments are statistically and significantly stationary on the level of $1 \%$, industrial production index and export data include unit root. For this reason, nonstationary series should be made stationary by differencing the nonstationary series. When the first differencing of industrial production index IP and export data EXP was performed, the data became statistically and significantly stationary on the level of $1 \%$.

\subsubsection{Ng-Perron Unit Root Test}

The weak side of ADF test is the addition of additional differences of the terms in the test equation to the model. For this reason, losses are experienced on the 
degree of freedom and the strength of the test decreases (Güvenek et al., 2010:7). For this reason, Ng Perron unit root test was used which gives stronger results in the testing of unit root.

$\mathrm{Ng}$ and Perron unit root test is a test which presents corrections related to the distribution and skewness of the size in other unit root tests (Tıraşoğlu and Yurttagüler, 2018: 317). Ng Perron unit root test, aims to eliminate the ADF unit root test restrictions by improving the 4 different test statistics and by using the generalized least-squares method (Ertuğrul and Soytaş, 2013:55).

$\mathrm{Ng}$ Perron unit root test results were given in Table 2.

Table 2: Ng Perron Unit Root Test

\section{Test Statistics}

\section{Critical Values}

\begin{tabular}{|c|c|c|c|c|c|c|}
\hline \multirow{2}{*}{ MSB } & \multirow{2}{*}{$\begin{array}{l}\text { MZa } \\
\text { MPT }\end{array}$} & \multirow[t]{2}{*}{$\mathrm{MZt}$} & \multicolumn{2}{|r|}{$(\% 1)$} & \multicolumn{2}{|c|}{$(\% 5)$} \\
\hline & & & $\begin{array}{l}\text { MZa } \\
\text { MSB }\end{array}$ & $\begin{array}{l}\text { MZt } \\
\text { MPT }\end{array}$ & $\begin{array}{l}\text { MZa } \\
\text { MSB }\end{array}$ & $\begin{array}{l}\text { MZt } \\
\text { MPT }\end{array}$ \\
\hline IPI & 0.040 & 0.01 & -13.8 & -2.58 & -8.1 & -1.98 \\
\hline 0.47 & 18.08 & & 0.17 & 1.78 & 0.23 & 3.17 \\
\hline PI & -13.44 & -2.58 & -13.8 & -2.58 & -8.1 & -1.98 \\
\hline 0.19 & 1.83 & & 0.17 & 1.78 & 0.23 & 3.17 \\
\hline EXP & 0.653 & 0.39 & -13.8 & -2.58 & -8.1 & -1.98 \\
\hline 0.60 & 28.39 & & 0.17 & 1.78 & 0.23 & 3.17 \\
\hline$\Delta \mathrm{IPI}$ & -7.372 & -1.91 & -13.8 & -2.58 & -8.1 & -1.98 \\
\hline 0.25 & 3.33 & & 0.17 & 1.78 & 0.23 & 3.17 \\
\hline$\Delta \mathrm{EX}$ & -62.09 & -5.53 & -13.8 & -2.58 & -8.1 & -1.98 \\
\hline 0.08 & 0.47 & & 0.17 & 1.78 & 0.23 & 3.17 \\
\hline
\end{tabular}


According to Table 2, while the portfolio investments are stationary, industrial production index and export data include unit root. For this reason, the series were made stationary by differencing the first difference of these series. The results from the $\mathrm{Ng}$ Perron unit root test also verify the findings that were obtained from ADF unit root test.

\subsection{Toda Yamamoto Causality Test}

After the unit root test situation in the series is examined, causality relationship between the series are analyzed. For the analysis of causality relationship, TodaYamamoto causality test was used due to its relative superiorities (especially enabling to use the series together when they are stationary on different degrees), compared to other tests. In the Toda-Yamamoto causality test, regardless of on which degree the variables are cointegrated, they are added to the analysis and the information loss problem that is experienced in long-term in Granger causality test is solved (Pata, 2018: 103). For this reason, TodaYamamoto causality test provides presenting more information in the series and giving more successful results (Çil Yavuz, 2006: 169).

Before conducting the Toda-Yamamoto causality test, the lag lengths should be detected in order to determine the lagged data that would reveal the causality relationships in the study. For this reason, six different tests were conducted in order to determine the lag length. In Table 3, the results for lag length testing for the model were given collectively. 
Table 3: Determination of Lag Length

\begin{tabular}{|c|c|c|c|c|c|c|}
\hline Lag & $\log \mathrm{L}$ & LR & FPE & AIC & $\mathrm{SC}$ & HQ \\
\hline \multirow{4}{*}{0} & - & & & & & \\
\hline & 1030.6 & & $8.08 \mathrm{e}+$ & & 40.650 & \\
\hline & 88 & NA & 13 & 40.53679 & 43 & 40.58022 \\
\hline & 950.02 & & $4.87 \mathrm{e}+$ & & 38.181 & \\
\hline \multirow[t]{2}{*}{1} & $\begin{array}{l}58 \\
-\end{array}$ & 148.6721 & 12 & 37.72650 & 05 & 37.90020 \\
\hline & 931.48 & & $3.36 \mathrm{e}+$ & & 38.14 & 37.6564 \\
\hline \multirow[t]{2}{*}{2} & $\begin{array}{l}72 \\
-\end{array}$ & 31.98802 & 12 & 37.35244 & $790 *$ & $1^{*}$ \\
\hline & 921.12 & & $3.22 \mathrm{e}+$ & & 38.435 & \\
\hline \multirow[t]{2}{*}{3} & $\begin{array}{c}73 \\
-\end{array}$ & 16.65723 & 12 & 37.29911 & 48 & 37.73335 \\
\hline & 910.31 & & $3.06 \mathrm{e}+$ & & 38.705 & \\
\hline \multirow[t]{2}{*}{4} & $\begin{array}{c}37 \\
-\end{array}$ & 16.11426 & 12 & 37.22799 & 27 & 37.79250 \\
\hline & 897.72 & 17.2844 & $2.74 \mathrm{e}$ & 37.08709 & 38.905 & \\
\hline 5 & 08 & $9^{*}$ & $+12 *$ & $*$ & 28 & 37.78187 \\
\hline
\end{tabular}

The results in Table 3 were interpreted and due to their relative superiorities, it was found appropriate to take two lag lengths that were given together by Schwartz Information Criterion and Hannah-Quinn Information Criterion.

After this process, since the series are stationary on different degrees, TodaYamamoto causality test was conducted on the model and the estimated results of the model were given in Table 4. 
Table 4: Toda-Yamamoto Causality Test Results

\begin{tabular}{|l|l|l|}
\hline $\begin{array}{l}\text { The Direction of the } \\
\text { Causality }\end{array}$ & Chi-sq & Prob. \\
\hline PI $\rightarrow$ IPI & 0.418983 & 0.9948 \\
\hline EXP $\rightarrow$ IPI & 5.053264 & 0.4094 \\
\hline IPI $\rightarrow$ PI & 1.727783 & 0.8854 \\
\hline IPI $\rightarrow$ EXP & 18.68392 & 0.0022 \\
\hline
\end{tabular}

According to Table 4, there wasn't a statistically significant causal relationship between the portfolio investment variable (PI) and the industrial production index (IPI) and between export (EXP) and industrial production index (IPI). This result reveals that the Dutch disease does not apply to Turkey for the examined period. In the analysis, statistically significant findings were found only between industrial production index (IPI) and export (EXP). Export increases, as the industrial production increases.

\section{Result:}

The Dutch disease which can be a subject for trade in theory and therefore, emerge as a result of the wealth of natural resources that can be exported, is an economical problem that has effects on many macroeconomic variables. However, the Dutch disease does not only emerge as a result of the possession and exportation of natural resource. According to the studies, all the economical activities and developments that cause an inflow of foreign currency may have effects on the Dutch disease. In this context, in Turkey of which inflow of foreign currency takes place in various ways, whether or not portfolio investments and export revenues create an effect of the Dutch disease on manufacturing industry or in other words, whether or not the Dutch disease apply to Turkey has been an issue of concern. For this reason, in order to 
research whether or not the portfolio investments and export revenues in Turkey cause the Dutch disease, a data set was created by using the data of Turkey's 2005:Q1-2018Q4 period. This data set were tested with unit root tests respectively, and then were tested with Toda-Yamamoto causality analysis in order to determine the direction of relationship between the variables. According to the causality analysis result, a causal relationship from portfolio investments and export to industrial production index could not be determined. This result demonstrates that the Dutch disease does not apply to Turkey for the examined period. A causal relationship from portfolio investments and export revenues to industrial production, which is regarded as the closes variable to the economic growth, could not be found. In the causality analysis, a causality was determined only from industrial production index to export. As the industrial production index changes, the exportation in Turkey changes as well.

Although it was determined that the Dutch disease did not apply to Turkey for the examined period, in case of encountering this economical problem in the future, it is necessary to take required precautions on time and in this context, foreign exchange earnings should be obtained through increasing the real investments, especially through increasing the industrial production instead of getting into debt. In the next studies, it is suggested to test the hypothesis of the Dutch disease by researching a causal relationship from portfolio investments and export revenues to economic growth, by using the growth numbers instead of industrial production index as well as increasing the number of data. 


\section{REFERENCES}

Acosta, P., Lartey, E. K. K., \& Mandelman, F. S. (2009). Remittances and the Dutch Disease, Journal of International Economics, 79(1), 102-116.

Akay, H., K., Aklan, N., A, and Çınar M. (2016). Economic Growth and the Unemployment Rate in Turkey, Journal of Management and Economic Research 14(1), 209-226.

Akça, E. E. and Bal, E., (2017). Workers' Remittances and Dutch Disease: A Panel Data Analysis for Selected Countries, Eskişehir Osmangazi University Journal of Economics and Administrative Science, 12(2), 49-64.

Akçacı, T. and Karaata, A. (2014). The Paradoxical Effect of International Funds in Turkey: Dutch Disease, International Conference On Eurasian Economies 2014 inside Session 6B: International Economy I, p. 385-394, Ed. Sarı, S., Gencer ve Sözen, İ., Skopje - Macedonia

Aksu, L. (2017). The Analysis of The Relationship Between The EmploymentProductivity And Economic Growth in Turkey, Journal of Economic Policy Researches, 4(1), 39-94.

Aliev, U. T., (2013). Economic Advance, Living Standards and Inequality In Oil-Producing Former Soviet Union Countries, Economy of the Region, (4), 133-142.

Ar1, Ö. (2011). Workers' Remittances and Economic Growth Relation: a Dynamic Panel Data Analysis, Erciyes University Journal of Economics and Administrative Science, (38), 101-117.

Aytekin Koç, G. (2018). Economic Effects and Speculation of Hot Money Flows in the Scope of International Capital Movements, International Journal of Humanities and Education, 4(7), 191-214 
Benkhodj, M. H. (2014). Monetary Policy and the Ducth Disease Effect in an Oil Exporting Economy, International Economics, (138), 78-102.

Bourdet, Y. and Falck, H. (2006). Emigrants' Remittances and Dutch Disease in Cape Verde", International Economic Journal, 20(3), 267-284.

Boyraz, H. M. (2014). Hollanda Hastalığı Nedir?, http://politikaakademisi.org/2014/07/18/hollanda-hastaligi-nedir/ last accessed 16.12.2018.

Bulut, C. and Süleymanov, E. (2012). Importance of Economic Collaboration Between Azerbaijan and Turkey in Preventing Dutch Disease in Azerbaijan, International Symposium on Regional Coorperation and Development, 99117. https://ssrn.com/abstract=2172960.

Corden, W. M. and Neary J. P., (1982). Booming Sector And De Industrialisation In A Small Open Economy, The Economic Journal, 92(368), 825-848.

Çil Yavuz, N. (2006). Test for the Effect of Tourism Receipts on Economic Growth in Turkey: Structural Break And Causality Analysis, Journal of Doğuş University, 7(2), 162-171.

Demir, O., Kutlar, A. and Üzümcü, A. (2005), “The Role of Trade and Human Capital in Growth: Turkish Case, Kocaeli University Journal of Social Sciences Institute, (9),180-196.

Destek, M. A., Okumuş, İ and Yıldırım, A. (2017). The Dutch Disease Effect on Agricultural Value Added: Evidence from Azerbaijan, Kazakhstan, Kyrgyzstan and Uzbekistan, Bilig Journal, (83), p. 225-239.

Eğilmez, M. (2013). Per Capita İncome and Income Distribution İn Turkey. http://www.mahfiegilmez.com/2013/07/turkiyede-kisi-basna-gelir-vegelirin.html. last accessed 16.12.2018. 
Erdoğan, S. and Bozkurt, H. (2009). The Determinants of Current Account Deficit in Turkey: An Analysis With MGARCH Models, Journal of Finance and Finance Writings, 23(84),135-172.

Ertuğrul, H.M. and Soytaş, U. (2013). The Stationarity Properties of the Industrial Production Index, Economics, Businiess and Finance, 28 (328) 2013, 51-66.

Eşiyok, B. A. (2012). Current Account Deficit Problem In Turkish Economy And its Reasons, Finance, Politics \& Economic Reviews, 49(569), 63-86

Granger, C.W.J. and Newbold, P. (1974). Spurious Regressions in Econometrics. Journal of Econometrics, North Holland Publishing Company. 2 (1974) 111-120.

Grossman, G. M. and Helpman, E. (1990). Trade, Knowledge Spillovers, and Gowth, National Bureau of Economic Research (NBER) Working Paper Series, Working Paper No: 3485,1-12. https://www.nber.org/papers/w3485.

Gurbanov, (2012). Dutch Disease; Theory and Country Cases, Akis Publishing, İstanbul.

Gül, E. and Ekinci, A. (2006). The Causal Relationship Between Exchange Rates and Inflation in Turkey:1984-2003, Anadolu University Journal of the Institute of Social Sciences, 6, 91-105.

Güvenek, B., Alptekin, V. and Çetinkaya, M. (2010). Analysis With the Method of Working Between Inflation and Individual Taxes, Public-Business, 11(3), 128.

Gylfason, T. (2001). Natural Resources, Education and Economic Development, European Economic Review, (45), 847-859. 
Hasanov, F. (2013). Dutch Disease and the Azerbaijan Economy, Communist and Post-Communist Studies, 46(4), 463-480.

Humprey, T. M. (2004). Classical Deflation Theory, Federal Reserve Bank of Richmond Economic Quarterly, 90(1), 11-32.

Karacan, R. (2010). Interest, Exchange Rate Effects a Review on the Relation Between Macroeconomic Performance, Kocaeli University Journal of Social Sciences Institute, (20), 72-92.

Kutan, A. M. and Wyzan, M. L. (2005). Explaining the Real Exchange Rate in Kazakhstan, 1996-2003: Is Kazakhstan Vulnerable to the Dutch Disease?", Economic Systems, 29(2), 242-255.

Matsen, E. and Torvik, R. (2005). Optimal Dutch Disease, Journal of Development Economics, 78(2), 494-515.

Mercan, M. and Göçer, İ. (2014). Dutch Disease Risk in Central Asian Turkish Republics: An Empirical Analysis, Hacettepe University Journal of Economics and Administrative Science, 32(2), 251-274.

Mironov, V.V. and Petronevic, A.V. (2015). Discovering the Signs of Dutch Disease in Russia, Resources Policy, 46(2), 97-112.

Nowak, j. J. and Sahli, M., (2007). Coastal Tourism and 'Dutch Disease' in a Small Island Economy, Tourism Economics, 13, 49-65.

Örnek, İ. (2006). "Foreign Capital Flows Effect on Domestic Saving and Economic Growth: The Case of Turkey", Ankara University Journal of Faculty of Politics Science, 63-2, p. 199-217.

Parlakyıldız F.M. and Uçan, O. (2012). IMF Disease: Turkey Case, Paradoks Economics, Sociology and Policy Journal, 8(2), 25-39. 
Pata, U.K. (2018). Testing for Symmetric and Asymmetric Causality between Inflation, Savings and Economic Growth in Turkey, Journal of Finance, January-June 2018; 174, 92-111.

Peck, J. (2005). Places of Work, E. Sheppard, T. J. Barnes (ed.), A Companion to Economic Geography iç. Malden, MA: Blackwell Publishing, 133-148.

Petek, A. and Çelik, A. (2017). An Econometric Analysis of the Relationship Between Inflation, Exchange Rate, Export and Import in Turkey (1990-2015), Financial Political \& Economic Comments, 54 (626), 69-87.

Rajan, R. G. and Subramanian, A. (2011). Aid, Dutch Disease, and Manufacturing Growth Journal of Development Economics, 94(1), 106-118.

Roy, R. and Dixon, R. (2016). Workers' Remittances and the Dutch Disease in South Asian Countries, Applied Economics Letters, 23(6), 407-410.

Sarıtaş, H. (2011). Effects Of Workers' Remittances On The Balance Sheet Of The Central Bank Of Turkey, International Journal of Alanya Faculty of Business, 3(1), 163-182.

Seyidoğlu, H. (2009). Uluslararası İktisat-Teori, Politika ve Uygulama, (17. Baskı). Güzem Can Publishing, İstanbul.

Subaşat, T. (2001). Turkey's Current Account Deficit: Causes and Solutions, Journal of Economics and Society, (1), 26-34.

Süleymanov, E., and Hasanov, F. (2013). Impact of Azerbaijan Investment In Energy Sector of Turkey on Economic Collabaration of These Countries. Çankırı Karatekin University International Journal of Eurasian Strategy, 2(2), 73-100.

Taylor, T. (2002). The Truth About Globalization, The Public Interest, 147, 2444. 
Tıraşoğlu, M. and Yurttagüler, İ.M. (2018). Inflation Convergence in BRICS Countries: A Comprehensive Unit Root Test Analysis, The Journal of Operations Research, Statistics, Econometrics and Management Information Systems, 6( 2), 311-324.

Yardımcioğlu, F. and Gülmez, A. (2013). Dutch Disease in the OPEC Countries: An Econometric Analysis of the Relationship between Oil Prices and Economic Growth, Sosyoekonomi Journal, 19(19), 117-140. 